\title{
Effects of soy protein diet on digestive lumenal polyamines and colonic cell proliferation in pigs
}

\author{
Robert Benamouziga,b*, Sylvain Mahéa , Karima Meziani ${ }^{a}$, \\ Antoine Martinc ${ }^{c}$, Catherine Juste ${ }^{\mathrm{d}}$, Isabelle Catala ${ }^{\mathrm{d}}$, Daniel Toméa
}

${ }^{a}$ Unité Inra de nutrition humaine et de physiologie intestinale, Inra Paris-Grignon,

16, rue Claude-Bernard, 75231 Paris cedex 05, France

b Service de gastro-entérologie, Hôpital Avicenne, 125, rue de Stalingrad, 93009 Bobigny cedex, France

${ }^{c}$ Service d'anatomo-pathologie, Hôpital Avicenne, 125, rue de Stalingrad, 93009 Bobigny cedex, France

d Unité Inra d'écologie et de physiologie du système digestif, 78350 Jouy-en-Josas, France

(Received 1 October 1998; accepted 27 January 1999)

\begin{abstract}
This study was performed to determine whether erythrocyte and digestive lumenal polyamine concentrations are affected by a soy protein diet when compared to a casein diet. We also determined the effects of these diets on colonic cell proliferation. Sixteen pigs received either a $16 \%$ soy protein or casein diet for 25 days. The erythrocyte putrescine was higher in pigs fed the soy protein diet. Significant levels of polyamines were observed in the digestive lumen on both diets. Lumenal putrescine and cadaverine were higher in the proximal colon in the casein group. Lumenal spermidine was higher in the caecum and colon in the soy protein group. No significant differences in the ornithine decarboxylase activity nor in the proliferative cell nuclear antigen labelling index were observed in the colonic mucosa regardless of the regimen. These results indicate that the dietary source of protein induces significant changes in lumenal polyamines in the colon. The physiological effects of these changes need to be further investigated. (C Inra/Elsevier, Paris.
\end{abstract}

soy protein / polyamines / colon / cell proliferation / pig

Résumé - Effets d'un régime à base de protéines de soja sur les taux digestifs de polyamines et la prolifération cellulaire colique chez le porc. Les effets d'un régime à base de protéines de soja sur les concentrations globulaires et luminales digestives de polyamines ainsi que sur la prolifération cellulaire colique ont été évalués chez le porc en comparaison avec un régime à base de caséine ( $n=8$ par groupe). Les taux globulaires de putrescine étaient plus élevés dans le groupe soja. Des taux

\footnotetext{
* Correspondence and reprints

E-mail: robert.benamouzig@avc.ap-hop-paris.fr
} 
notables de polyamines ont été détectés dans la lumière intestinale et dans la lumière colique. Dans le côlon proximal, les concentrations de putrescine et de cadavérine étaient plus élevées dans le groupe caséine tandis que la concentration de spermidine était plus élevée dans le cæcum et le côlon proximal du groupe soja. Aucune modification significative de la prolifération cellulaire colique n'a été observée en fonction du régime. Cette étude a mis en évidence des modifications des taux globulaires et luminaux coliques de polyamines en fonction de la source protéique alimentaire dont les conséquences physiologiques éventuelles restent à préciser. (C) Inra/Elsevier, Paris.

\section{protéines de soja / polyamines / côlon / proliferation cellulaire / porc}

\section{INTRODUCTION}

The polyamines putrescine, spermidine and spermine are small polycationic molecules involved in a variety of cellular processes such as replication and transcription as well as cell proliferation and differentiation [17]. Cells possess two different pathways to regulate their polyamine contents, one is by enzymatic synthesis and interconversion and the other is by membrane exchange as the resultant of uptake, adhesion, absorption, transport and excretion [27]. The intestinal tract plays a central role in polyamine supply and homeostasis in the body. Polyamines enter the gastrointestinal tract from several sources, including the diet, digestive secretions, exfoliated cells and microflora synthesis [2,21]. Secreted endogenous polyamines and dietary polyamines are progressively absorbed along the intestine. Lumenal and endogenous polyamines may be used by the mucosa and small intestinal growth is stimulated after putrescine infusion into the rat small intestine [25]. In this regard, lumenal polyamines may be the primary source of extracellular polyamines for tumour growth in tumourbearing rodents $[5,26]$. Because of this evidence indicating that polyamines are necessary for optimal cell proliferation, a further investigation of the role of dietary components in the modulation of intestinal lumenal polyamine levels is important. Among nutrients, the specific role of dietary protein in intestinal polyamine metabolism is poorly known. Protein, an essential nutrient, affects many metabolic processes that are directly and indirectly related to tissue growth. Experimental studies suggest that soy protein may affect intestinal morphology and function $[18,28]$ as well as colonic cell proliferation and the development of intestinal tumours induced by dimethylhydrazine [7, $15,19]$. Furthermore intestinal epithelial cells possess high arginase activity, which converts L-arginine to L-ornithine, and are able to synthesise polyamines from amino acid precursors $[4,22,29]$. The present study is aimed at comparing intestinal and colonic lumenal polyamine concentrations as well as erythrocyte concentrations in pigs fed either a soy protein diet or a casein diet for 25 days. The colonic cell proliferation was also assessed by both the proliferative cell nuclear antigen (PCNA) technique and by determining the ornithine decarboxylase (ODC) activity.

\section{MATERIALS AND METHODS}

\subsection{Animals and diets}

Sixteen castrated male large white pigs with an initial body weight of $35 \pm 0.6 \mathrm{~kg}$ were housed in individual pens $(1.5 \times 1.8 \mathrm{~m})$ in a nursery maintained at $24-26^{\circ} \mathrm{C}$. They were allowed water ad libitum. The experimental diets were prepared by Inra (APAE, Jouy-en-Josas, France). They contained $16 \%$ of either casein or soy protein with the soy concentrate containing $66 \%$ protein and $19 \%$ fibre (Central Soy, Aarhus, Denmark) (table I). The amounts of putrescine, 
Table I. Percent composition of diets.

$16 \%$ casein regimen $16 \%$ soy regimen

Hydrochloric casein (\% fresh matter)

17.8

23.9

Soy concentrate (\% fresh matter)

Soy oil (\% fresh matter)

Corn starch (\% fresh matter)

Saccharose (\% fresh matter)

Cholesterol (\% fresh matter)

Cellulose ( $\%$ fresh matter)

$\beta$-cyclodextrin ( $\%$ fresh matter)

Mineral mix (\% fresh matter)

Vitamin mix (\% fresh matter)

Antioxidizing agent (\% fresh matter)

$\begin{array}{rr}15.0 & 14.2 \\ 38.3 & 37.7 \\ 14.5 & 14.3 \\ 0.3 & 0.3 \\ 5.0 & 0.5 \\ 5.0 & 5.0 \\ 3.0 & 3.0 \\ 1.0 & 1.0 \\ 0.1 & 0.1\end{array}$

spermidine and spermine were $0.15,0.09$ and $0.01 \mu$ moles $\cdot \mathrm{g}^{-1}$ in the casein diet, respectively, and $0.67,4.18$ and $0.35 \mu$ moles $g^{-1}$ in the soy protein diet, respectively. Traces of cadaverine were observed in the soy protein diet. All pigs were fed the $16 \%$ casein diet twice daily at 09.00 and 17.00 hours $(800 \mathrm{~g} / \mathrm{meal})$ for 1 week before the study period. After this period, they were randomly divided into two groups and were fed either the $16 \%$ casein diet $(n=8)$ or the $16 \%$ soybean protein diet $(n=8)$ twice daily at 09.00 and 17.00 hours $(800 \mathrm{~g} / \mathrm{meal})$ for 25 days. The mean weight increase of the animals during the study period ( $720 \mathrm{~g} /$ day) and the final weight $(54.3 \pm 1.8 \mathrm{~kg}$ for pigs fed casein and $52.9 \pm 1.5$ $\mathrm{kg}$ for pigs fed soybean protein) did not vary, regardless of the regimen. All experiments were conducted according to the guidelines for care and use of laboratory animals.

\subsection{Experimental procedure}

The experiments were performed after an overnight food deprivation in order to avoid any acute change in polyamine metabolism induced by refeeding. The pigs were anaesthetised and assisted respiration was maintained during the entire surgical procedure. The abdominal cavity was opened, and the jejunum, ileum, caecum, proximal colon and distal colon were ligated both at their proximal and distal ends. The mesentery was cut and each segment was quickly removed. The luminal contents were then pressed out of the intestinal segments, immediately frozen at $-30{ }^{\circ} \mathrm{C}$ and then freeze-dried. Duplicate tissue samples were prepared from each segment. The first portion was fixed in a $10 \%$ phosphatebuffered formalin for standard histological examination and immunohistochemistry. The mucosa of the second portion was scraped with a glass slide and immediately frozen in liquid nitrogen, then stored at $-70{ }^{\circ} \mathrm{C}$ until ODC analysis. Peripheral blood samples were collected prior to the procedure. Portal blood samples were collected at the beginning of the surgical procedure.

\subsection{Polyamine measurement}

Washed erythrocytes were prepared for the polyamine assay, as previously described [20]. Erythrocyte and luminal polyamines were assayed in $1 \mathrm{~mL}$ of perchloric acid extract by a dansylation procedure and were then analysed by HPLC using a Waters gradient HPLC system with a $5-\mu \mathrm{m}$ reverse phase $\mathrm{C}_{18}$ column (Paris, France) and a fluorescence detector (Waters 420), as previously described [23]. The compounds were identified by their relative retention times and quantified by comparing peak areas to those of known amounts of 1,6 diaminohexane used as an internal standard. Peak area responses were linear over the test range.

\subsection{ODC assay and protein determination}

The activity of the enzyme ODC was assayed by a radiometric technique in which ${ }^{14} \mathrm{CO}_{2}$ was 
liberated from L-[ $\left[1-{ }^{14} \mathrm{C}\right]$-ornithine [11]. Briefly, 50-60 mg of tissue specimens were homogenised, with a polytron, at $0-4{ }^{\circ} \mathrm{C}$ in $1 \mathrm{~mL}$ $25 \mathrm{mmol} \cdot \mathrm{L}^{-1}$ Tris- $\mathrm{HCl}$ buffer, $\mathrm{pH} 7.5$ containing $2.5 \mathrm{mmol} \cdot \mathrm{L}^{-1}$ dithiotreitol, $0.1 \mathrm{mmol} \cdot \mathrm{L}^{-1}$ EDTA and $0.2 \mathrm{mmol} \cdot \mathrm{L}^{-1}$ pyridoxal phosphate. The homogenate was centrifuged at $3000 \mathrm{~g}$ for $20 \mathrm{~min}$ and $200 \mu \mathrm{L}$ of the supernatant was incubated for $2 \mathrm{~h}$ in a $37^{\circ} \mathrm{C}$ gyrotory shaker bath with $25 \mathrm{mmol} \cdot \mathrm{L}^{-1}$ Tris- $\mathrm{HCl} \mathrm{pH} \mathrm{7.5,} 2.5 \mathrm{mmol} \cdot \mathrm{L}^{-1}$ dithiotreitol, $0.1 \mathrm{mmol} \cdot \mathrm{L}^{-1}$ EDTA, $0.2 \mathrm{mmol} \cdot \mathrm{L}^{-1}$ pyridoxal phosphate and $10 \mathrm{mmol} \cdot \mathrm{L}^{-1} \mathrm{~L}$-ornithine using $\mathrm{L}-\left[1-{ }^{14} \mathrm{C}\right]$-ornithine $(57 \mathrm{mCi} / \mathrm{mmol}$, Amersham, UK) as a tracer. Assays were performed in stoppered Erlenmeyer flasks fitted with a centre well containing $0.5 \mathrm{~mL}$ of $\beta$-phenylethylamine in order to trap the released ${ }^{14} \mathrm{CO}_{2}$. The reaction was stopped by injecting $80 \mu \mathrm{L}$ of $0.4 \mathrm{M} \mathrm{HClO}_{4}$. The flasks were shaken for an additional hour in order to ensure complete recovery of the released $\mathrm{CO}_{2}$ in $\beta$-phenylethylamine. The well contents were then added to $6 \mathrm{~mL}$ of Dynagel and the radioactivity was determined using a Beckman LS 9000 scintillation counter. Values were corrected for the counts in blanks without the enzyme. All assays were performed twice. Enzyme activity was expressed as pmoles ${ }^{14} \mathrm{CO}_{2}$ formed per hour per mg of protein tissue. Protein concentration was assayed according to the Bradford method [6], using bovine serum albumin as the standard.

\subsection{PCNA protocol}

For the PCNA immunoreaction, distal colonic tissue specimens were fixed overnight in a $10 \%$ buffered formalin, then flattened, orthogonally sectioned and paraffin-embedded. Before establishing the final protocol, various tissue fixation methods were compared to investigate their influence on staining intensity. As an alternative to $10 \%$ buffered formalin, biopsy samples were also fixed for 18-24 $\mathrm{h}$ in Bouin solution, $70 \%$ ethanol and absolute methanol. Proliferative cells were labelled by immunohistochemistry with a mouse monoclonal antibody against PCNA (PC10, IgG2a, Kappa-Dako, Trappes, France). This isotype is known to react with PCNA from all vertebrate species and our preliminary tests confirmed the ability of the antibody to label the proliferative compartment in pits and in the lymphoid follicles of the pigs' intestine. A streptavidin-biotin-peroxidase method was used to reveal the reaction. Paraffin sections $(4 \mu \mathrm{m})$ were dewaxed in xylene and progressively rehydrated through graded ethanol to a $50 \mathrm{mmol} \cdot \mathrm{L}^{-1}$ Tris buffered saline solution (TBS) pH 7.4. Endogenous peroxidase activity was blocked by adding $3 \%$ hydrogen peroxide $\left(\mathrm{H}_{2} \mathrm{O}_{2}\right)$ for $10 \mathrm{~min}$. After rinsing once in distilled water, then twice in TBS for $5 \mathrm{~min}$, the slides were placed in normal serum for $15 \mathrm{~min}$. They were then incubated for $30 \mathrm{~min}$ with the PC10 antibody and diluted 1/20 in TBS pH 7.5 containing $1 / 20$ normal goat serum (Dako). The antibody reaction was accessed with a labelled streptavidin-biotin kit (LSAB, Dako) according to the manufacturer's instructions and visualised with a substrate solution containing $0.01 \% 3,3$-diaminobenzidine (Dako) and $0.02 \%$ $\mathrm{H}_{2} \mathrm{O}_{2}$ in TBS pH 7.6. After being washed in distilled water, the slides were dehydrated and counterstained in Mayer's haematoxylin for a few seconds and mounted using a synthetic mounting medium (Histolabs, Sweden). Slides were viewed using a Zeiss microscope together with a computed image analyser (Biocom 2000, France) at $\times 200$. At least eight well-oriented crypts were counted from each sample. The crypt columns were merged into a single histogram and then divided into three regions, the lowest third of the crypt being region 1 , the middle third region 2 and the upper third including the luminal surface region 3. A cell was scored as 'positive' for PCNA when the nucleus was distinctly brown stained. The labelling index was determined by calculating the ratio of the number of positive cells to the total number of cells, both in the whole crypt and in each region. A human node with follicular lymphoid hyperplasia was included in each trial as a positive control. The same pig colonic sample was also included in each trial for standardisation purposes. Furthermore, all slides were counted twice by the same observer to minimise any intra-observer variation.

\subsection{Statistical analysis}

Data are given as means \pm SEM. The statistical significance of the results was evaluated using the non-parametric Mann-Whitney ranking test and the ANOVA procedure with a posteriori contrast using Scheffe's test whenever relevant. All of these procedures were performed with Statview (Abacus Concept, USA). Differences with a $P$ level lower than 0.05 were considered to be significant. 


\section{RESULTS}

\subsection{Erythrocyte polyamines}

The levels of putrescine, spermidine and spermine were measured in the erythrocytes from both peripheral and portal blood in both groups of pigs after being deprived of food overnight (table II). The origin of the blood samples did not significantly affect the erythrocyte polyamine concentration but for both diets the putrescine content was higher and spermine content lower in peripheral blood than in portal blood. The erythrocyte putrescine concentration was higher in the soy protein group than in the casein group $(P<0.01)$. The spermidine and spermine erythrocyte concentrations were also slightly higher in the soy protein group but these differences did not reach a significant level $(P=0.28-0.47)$.

\subsection{Lumenal polyamines}

There were significant differences in putrescine, spermidine and spermine concentrations in the digestive lumen of the pig during the fasting state (table III). In the intestinal lumen, the dominant polyamine was spermine, whereas in the caecal and colonic lumen, the dominant polyamines were putrescine and cadaverine. Despite the regimen, lumenal spermidine and spermine concentrations were higher in the ileum than in the jejunum $(P<0.05)$. Only very low levels of cadaverine were observed both in the ileum and in the jejunum lumen. Lumenal putrescine, cadaverine and spermidine concentrations were 3-35 times higher in the caecal and proximal colonic lumen than in the intestinal lumen $(P<0.005)$, but spermine concentration was higher in the ileum than in the caecum and colon $(P<0.001)$. Lumenal putrescine, spermidine and spermine were higher in the caecum and proximal colon than in the distal colon $(P<0.05)$.

The protein source did not affect the polyamine concentrations either in the jejunum or in the ileum lumen. In the caecum, no significant differences were observed for putrescine, cadaverine and spermine concentrations with regards to the protein source, but the spermidine concentration was higher with the soy protein regimen. In the proximal colon, higher putrescine and cadaverine lumenal concentrations were observed with the casein regimen, but the spermidine concentration remained higher with the soy protein regimen. In the distal colon, a higher cadaverine concentration was also observed with the casein diet but the other polyamine concentrations did not vary with regards the diet.

\subsection{Colonic cell proliferation and ODC activity}

Approximately 1000 colonic epithelial cells were evaluated per sample (range:

Table II. Erythrocyte polyamine levels in peripheral and portal blood samples.

\begin{tabular}{lccccc}
\hline & \multicolumn{2}{c}{ Casein $(n=8)$} & & \multicolumn{2}{c}{ Soy protein $(n=8)$} \\
\cline { 2 - 3 } \cline { 5 - 6 } $\begin{array}{l}(\mu \text { moles per } \mathrm{mL} \\
\text { packed erythrocytes })\end{array}$ & Peripheral blood & Portal blood & & Peripheral blood & Portal blood \\
\hline Putrescine & & & & \\
Spermidine & $6.47 \pm 3.14$ & $2.13 \pm 0.75$ & & $18.40 \pm 6.51^{*}$ & $11.81 \pm 2.95^{*}$ \\
Spermine & $73.10 \pm 9.42$ & $74.15 \pm 10.42$ & & $96.18 \pm 16.45$ & $92.32 \pm 20.02$ \\
& $10.54 \pm 2.82$ & $16.80 \pm 4.49$ & & $13.51 \pm 5.66$ & $23.81 \pm 7.69$ \\
\hline
\end{tabular}

Data are expressed as means $\pm \mathrm{SEM} ; n=$ number of animals per treatment group.

* Indicates a significant difference between the regimens by Scheffe's test $(P<0.05)$. 
Table III. Lumenal polyamines.

\begin{tabular}{|c|c|c|}
\hline \multicolumn{3}{|c|}{ Lumenal polyamines ( $\mu$ moles $\cdot \mathrm{g}^{-1}$ dry matter) } \\
\hline & Casein diet & Soy protein diet \\
\hline \multicolumn{3}{|l|}{ Putrescine } \\
\hline Jejunum & $0.75 \pm 0.15^{\mathrm{A}, \mathrm{a}}$ & $4.32 \pm 3.49^{\mathrm{A}, \mathrm{a}}$ \\
\hline Ileum & $8.59 \pm 3.97^{\mathrm{A}, \mathrm{a}}$ & $3.34 \pm 1.05^{\mathrm{A}, \mathrm{a}}$ \\
\hline Caecum & $74.05 \pm 22.57^{\mathrm{A}, \mathrm{a}}$ & $68.97 \pm 18.01^{\mathrm{A}, \mathrm{a}}$ \\
\hline Proximal colon & $89.37 \pm 24.72^{\text {A. a }}$ & $15.55 \pm 4.73^{\mathrm{B}, \mathrm{b}}$ \\
\hline Distal colon & $14.72 \pm 12.73^{\mathrm{A} . \mathrm{a}}$ & $16.54 \pm 15.14^{\mathrm{A}, \mathrm{a}}$ \\
\hline \multicolumn{3}{|l|}{ Cadaverine } \\
\hline Jejunum & $0.14 \pm 0.03^{\mathrm{A}, \mathrm{a}}$ & $1.82 \pm 1.68^{\mathrm{A}, \mathrm{a}}$ \\
\hline Ileum & $1.03 \pm 1.23^{\mathrm{A} . \mathrm{a}}$ & $0.51 \pm 0.55^{\mathrm{A}}$ \\
\hline Caecum & $82.83 \pm 23.35^{\text {в. а }}$ & $43.34 \pm 12.74^{\mathrm{B}, \mathrm{b}}$ \\
\hline Proximal colon & $92.26 \pm 20.32^{\mathrm{B} . \mathrm{a}}$ & $8.65 \pm 2.85^{\mathrm{B} . \mathrm{b}}$ \\
\hline Distal colon & $128.37 \pm 56.27^{\mathrm{B}, \mathrm{a}}$ & $11.85 \pm 11.52^{\mathrm{B} . \mathrm{b}}$ \\
\hline \multicolumn{3}{|l|}{ Spermidine } \\
\hline Jejunum & $0.99 \pm 0.16^{\mathrm{A}, \mathrm{a}}$ & $1.52 \pm 0.31^{\mathrm{A} a}$ \\
\hline Ileum & $3.38 \pm 0.81^{\mathrm{B}, \mathrm{a}}$ & $5.65 \pm 1.74^{\mathrm{B} . \mathrm{a}}$ \\
\hline Caecum & $16.12 \pm 4.18^{\mathrm{C} \cdot a}$ & $46.54 \pm 7.83^{\mathrm{c}, \mathrm{b}}$ \\
\hline Proximal colon & $12.87 \pm 3.90^{\mathrm{C}, \mathrm{a}}$ & $25.84 \pm 3.79 \mathrm{c}, \mathrm{b}$ \\
\hline Distal colon & $2.09 \pm 0.42^{\mathrm{B}, \mathrm{a}}$ & $4.52 \pm 1.03 \mathrm{k}$ \\
\hline \multicolumn{3}{|l|}{ Spermine } \\
\hline Jejunum & $8.60 \pm 2.39^{\mathrm{A}, \mathrm{a}}$ & $11.45 \pm 3.31^{\mathrm{A}, \mathrm{a}}$ \\
\hline Ileum & $26.46 \pm 5.71^{\mathrm{B} . \mathrm{a}}$ & $17.92 \pm 8.20^{\mathrm{Ba}}$ \\
\hline Caecum & $13.66 \pm 3.66^{\mathrm{A} \cdot \mathrm{a}}$ & $15.48 \pm 4.81^{\mathrm{A}, \mathrm{a}}$ \\
\hline Proximal colon & $4.29 \pm 2.04 \mathrm{C}, \mathrm{a}$ & $2.11 \pm 0.25 \mathrm{c}, \mathrm{a}$ \\
\hline Distal colon & $0.40 \pm 0.11^{\mathrm{D}, \mathrm{a}}$ & $0.19 \pm 0.02^{\mathrm{D}, \mathrm{a}}$ \\
\hline
\end{tabular}

A. B.C.I) indicate a significant difference between sites; ${ }^{a}$ b indicate a significant difference between the regimens by Scheffe's test $(P<0.05)$.

837-1041) to evaluate the PCNA labelling index which was assumed to represent the $S$ phase cells. The PCNA labelling index did not vary with regards to the regimen (table IV).

ODC activity in the pig colonic mucosa was $270 \pm 47 \mathrm{pmole}{ }^{14} \mathrm{CO}_{2} \cdot \mathrm{h}^{-1} \cdot \mathrm{mg}^{-1}$ protein (range: 17-526). The ODC activity did not vary with regards the regimen. There is a poor correlation between the measures of ODC activity and the PCNA labelling index, both in the whole crypt and in the upper, middle and lower parts of the crypt $(P=0.85-0.97)$.

\section{DISCUSSION}

The present study was performed in order to evaluate the influence of a soy protein diet when compared to a casein diet on polyamine levels in erythrocytes and in digestive lumen in pigs.

It is interesting to note that the soy protein diet is associated with a higher level of putrescine in blood erythrocytes when compared to the casein diet. The soy protein diet has a higher polyamine content than the casein diet and these dietary polyamines are absorbed by the intestinal mucosa before 
Table IV. Labelling index and ODC activity in the colonic mucosa of pigs fed $16 \%$ casein and $16 \%$ soy protein diet.

\begin{tabular}{lccl}
\hline & $\begin{array}{c}\text { Casein diet } \\
(n=7)\end{array}$ & $\begin{array}{c}\text { Soy diet } \\
(n=8)\end{array}$ & $P$ \\
\hline No. cells per individual & $896 \pm 9$ & $913 \pm 23$ & NS \\
LI region 1 (\%) & $0.12 \pm 0.04$ & $0.15 \pm 0.06$ & NS \\
LI region 2(\%) & $0.24 \pm 0.08$ & $0.27 \pm 0.08$ & NS \\
LI region 3 (\%) & $0.35 \pm 0.05$ & $0.35 \pm 0.05$ & NS \\
LI total $(\%)$ & $0.23 \pm 0.06$ & $0.25 \pm 0.06$ & NS \\
ODC activity & $347 \pm 58$ & $194 \pm 66$ & NS \\
$\left(\mu\right.$ mole ${ }^{14} \mathrm{CO}_{2} \cdot \mathrm{h}^{-1} \cdot \mathrm{mg} \cdot$ protein $\left.^{-1}\right)$ & & & \\
\hline
\end{tabular}

Data are expressed as means $\pm \mathrm{SEM} ; n=$ number of animals per treatment group.

entering the blood circulation. These data suggest the contribution of dietary polyamines to the polyamine body pools since over $95 \%$ of the polyamines are transported in the blood by erythrocytes.

High lumenal polyamine concentrations were observed in the digestive lumen with the highest found in the caecum and colon for putrescine and cadaverine and in the intestine for spermine. The polyamine levels observed in the pigs' intestine are closer in range than those previously reported in rats [16, 21] and in healthy humans [3]. In rats, the highest lumenal concentrations of polyamines were observed in the jejunum, indicating a polyamine supply in the upper part of the intestine and subsequent absorption along the intestine from the jejunum to the ileum [21]. This pattern was not observed in the present study. The long fasting period used before sampling could allow for a more complete absorption of dietary polyamines and explain, at least in part, this discrepancy. The presence of significant polyamines in the fasted state of the gut lumen could also suggest the movements of polyamines from circulation/erythrocyte to gut lumen. This hypothesis is strengthened by the absence of a difference in lumenal polyamine intestinal levels between regi- mens despite their different polyamine concentrations.

The presence of traces of antinutrients such as trypsin inhibitors in the soy protein diet that might influence the polyamine metabolism was not addressed in this study. However, the absence of any variation in intestinal lumenal polyamine levels according to the diet does not indicate the presence of these agents at least at a level of physiological importance.

Another interesting result was the high levels of lumenal polyamines in the caecum and colon. The polyamine concentrations in the colonic lumen have been quantified in only a few studies. These levels are higher than those previously observed in the colonic lumen of rats [21], but similar to those reported in human faeces $[12,13]$. The origin of colonic polyamines remains to be determined. The small bowel polyamines appear to be of limited contribution since they are progressively absorbed by the intestinal mucosa from the duodenum to the ileum $[1,9,10]$. A dietary origin cannot, however, be ruled out and the higher spermidine levels observed in the soy protein group in the caecum and proximal colon could be related to the higher spermidine dietary supply. The high levels of putrescine 
and cadaverine associated with relatively low levels of spermine suggest a predominant bacterial origin. Polyamines could originate from the transformation by the microflora of dietary or endogenous protein that escapes digestion and absorption in the small intestine $[8,14]$. In fact, putrescine could come from ornithine, which rarely occurs in proteins. Thus, the changes observed among regimens in colonic putrescine and cadaverine suggest variations in the bacterial fermentation process of proteinaceous material according to the dietary protein source. It is possible that the soy protein diet favours special species of bacteria which produce spermidine. The possible physiological consequences of these changes remain to be investigated.

The polyamine present in intact bacteria could not be specifically delineated from those released from dead bacteria or from another origin (released by the mucosa, etc.) according to our experimental procedures. However, since polyamines present in intact bacteria could be released and exchanged with those present in the lumen, the whole lumenal polyamine content seems to be of physiological relevance.

The dietary protein source and particularly soy protein could influence the small intestine morphology and function [18, 24, $28]$. Soy protein was also reported to increase colonic cell proliferation [15] and induce colorectal carcinogenesis [19]. In this study, the soy protein diet was not associated with an increase in colonic cell proliferation. This discrepancy could be explained by either variations in the experimental procedure, interspecies differences or changes in the quality of the soy products used.

In conclusion, significant levels of polyamines were observed in the digestive lumen in pigs. Significant changes in lumenal polyamines were observed according to the dietary source of protein in the colon. These changes were not associated with detectable modification of labelling index.
Then, the physiological effects of these changes need to be further investigated.

\section{ACKNOWLEDGEMENT}

We thank Rebecca Garcia and Henriette Drouet for their excellent technical assistance and Nicolas Gausserès for his friendly help. This work was supported in part by a grant from the Association pour la Recherche sur le Cancer, Villejuif, France. This work is part of the Eu-Cost Action 917.

\section{REFERENCES}

[1] Bardocz S., Brown S., Grant G., Pusztai A., Luminal and basolateral polyamine uptake by rat small intestine stimulated to grow by $P h a-$ seolus vulgaris lectin phytohaemagglutinin in vivo, Biochim. Biophys. Acta. 1034 (1990) 46-52.

[2] Bardocz S., Duguid T., Brown D., Grant G. Pusztai A., White A., Ralph A., The importance of dietary polyamines in cell regeneration and growth, Br. J. Nutr. 73 (1995) 819-828.

[3] Benamouzig R., Mahé S., Luengo C., Rautureau J., Tomé D., Fasting and post-prandial polyamine levels in the human digestive lumen, Am. J. Clin. Nutr. 65 (1997) 766-770.

[4] Blachier F., Darcy-Vrillon B., Sener A., Duee P.H. Malaisse W.J., Arginine metabolism in rat enterocytes, Biochim. Biophys. Acta 1092 (1991) 304-310.

[5] Brachet P., Quemener V., Havouis R., Tomé D. Moulinoux J.P., Alterations in intestinal uptake of putrescine and tissue polyamine concentrations in tumor-bearing rats, Biochim. Biophys. Acta 1227 (1994) 161-170.

[6] Bradford M.M., A rapid and sensitive method for the quantification of microgram quantities of protein utilizing the principle of protein-dye binding, Analyt. Biochem. 72 (1976) 248-254.

[7] Clinton S.K., Destree R.J., Anderson D.B. Truex C.R., Imrey P.B., Visek W.J., 1,2 Dimethylhydrazine induced intestinal cancer in rats fed beef or soybean protein, Nutr. Rep. Int. 20 (1979) 335-342.

[8] Cummings J.H., Macfarlane G.T., The control and consequences of bacterial fermentation in the human colon, J. Appl. Bacteriol. 70 (1991) 443-459.

[9] Dorhout B., Van Faassen A., Van Beusekom C., Kingma A., De Hoog E., Nagel G., Karrenbeld A., Boersma E., Muskiet F., Oral administration of deuterium-labelled polyamines to suckling rat pups: luminal uptake, metabolic fate and effects on gastrointestinal maturation, Br. J. Nutr. 78 (1997) $639 \ldots 654$. 
[10] Dumontier A.M., Brachet P., Huneau J.F., Tomé D., Transport of putrescine in the isolated rabbit intestine, Eur. J. Physiol. 420 (1992) 329-335.

[11] Erwin B.G., Seely J.E., Pegg A.E., Mechanism of stimulation of ornithine decarboxylase activity in transformed mouse fibroblasts, Biochemistry 22 (1983) 3027-3032.

[12] Forget P., Degraeuwe P.L.J., Smeets C., Deutz N.E.P., Fasting gastric fluid and fecal polyamine concentrations in premature infants, J. Pediat. Gastroenterol. Nutr. 24 (1997) 389-392.

[13] Forget P., Sinaasappel M., Bouquet J., Deutz N.E., Smeets C., Fecal polyamine concentration in children with and without nutrient malabsorption, J. Pediat. Gastroenterol. Nutr. 24 (1997) 285-288.

[14] Geypens B., Claus D., Evenepoel P., Hiele M., Maes B., Peeters M., Rutgeerts P., Ghoos Y., Influence of dietary protein supplements on the formation of bacterial metabolites in the colon, Gut 41 (1997) 70-76.

[15] Govers M., Lapré J., DeVries H., VanderMeer R., Dietary soybean protein compared with casein damages colonic epithelium and stimulates colonic epithelial proliferation in rats, J. Nutr. 123 (1993) 1709-1713.

[16] Iwami K., Terabe N., Kobayashi T., Ibuki F., Postprandial changes in ornithine decarboxylase activity and the mucosal and intraluminal levels in the small intestine of rats concerning the significance of intestinal putrescine absorption, Biosci. Biotech. Biochem. 58 (1994) 1357-1363.

[17] Jänne J., Alhonen L., Leinonen P., Polyamines: From molecular biology to clinical applications, Ann. Med. 23 (1991) 241-259.

[18] Makkink C.A., Negulescu G.P., Qin G., Verstegen M.W., Effect of dietary protein source on feed intake, growth, pancreatic enzyme activities and jejunal morphology in newly-weaned piglets, Br. J. Nutr. 72 (1994) 353-368.

[19] McIntosh G., Regester G., LeLeu R., Royle P., Smithers G., Dairy proteins protect against dimethylhydrazine induced intestinal cancers in rats, J. Nutr. 125 (1995) 809-816.
[20] Moulinoux J.P., Quemener V., Larzul J.J, LeCalve M., Roch A.M., Toujas L., Quash G., Red blood cell polyamines in mice bearing the Lewis Lung Carcinoma (3LL) and in patients with bronchopulmonary cancers, Int. J. Cancer 34 ( 1984) 277-281.

[21] Osborne D.L., Seidel E.R., Gastrointestinal luminal polyamines: cellular accumulation and enterohepatic circulation, Am. J. Physiol. 258 (1990) G576-G584.

[22] Raul F., Galluser M., Schleiffer R., Gosse F., Hasselmann M., Seiler N., Beneficial effects of L-arginine on intestinal epithelial restitution after ischemic damage in rats, Digestion 56 (1995) 400-405

[23] Saeki Y., Uehara N., Shirakawa S., Sensitive fluorimetric method for the determination of putrescine, spermidine and spermine by highperformance liquid chromatography and its application to human blood, J. Chromatogr. 145 (1978) 221-229.

[24] Seegraber F.J., Morrill J.L., Effect of protein source in calf milk replacers on morphology and absorptive ability of small intestine, J. Dairy Sci. 69 (1986) 460-469.

[25] Seidel E.R., Snyder R.G., Johnson L.R., Ileal mucosa growth during intraluminal infusion of ethylamine or putrescine, Am. J. Physiol. 249 (1985) G434-G438.

[26] Seiler N., Sarhan S., Grauffel C., Jones R., Knodgen B., Moulinoux J.P., Endogenous and exogenous polyamines in support of tumor growth, Cancer Res. 50 (1990) 5077-5083.

[27] Seiler N., Delcros J.G., Moulinoux J.P., Polyamine transport in mammalian cells. An update, Int. J. Biochem. Cell. Biol. 28 (1996) 843-861.

[28] Tamura M., Suzuki H., Effects of soy protein on the morphology of ileum and the ultrastructure of liver cells in adult mice, Int. J. Vitam. Nutr. Res. 68 (1998) 73-76.

[29] Wu G., Urea synthesis in enterocytes of developing pigs, Biochem. J. 312 (1995) 717-723. 